\title{
"The effects of physical exercises in the morning and evening time on some physiological parameters"
}

\author{
https://doi.org/10.32792/utq/utj/vol11/3/1
}

\begin{abstract}
Shatha Q. Al-temimi;Hanaa S. Kadhem ${ }^{* *}$;Mahdi M. Thuwaini****
*Msc. medical Science, department of Basic Science, College of Dentistry, University of Basrah, Iraq; ** Ph.D., Physiology, College of Science, Biology Department / University of Basra, Iraq ***Ph.D. Pathology, College of Nursing/Thi-Qar University, Iraq Corresponding author: department of Basic Science, College of Dentistry, University of Basrah ,Basrah, Iraq . shatha.basrah@gmail.com
\end{abstract}

\begin{abstract}
The present study aimed to compare the effect of physical exercise in the morning and evening time on some physiological parameters which comprised from renal function test including blood urea nitrogen (BUN), serum creatinine (S.cr), some of serum electrolyte. (sodium and potassium) and blood pressure. The study included (20) males students volunteers of the second stage - College of Physical Education University of Basra (10) students from the morning group and (10) students from the evening group. The results Showed that The Bun and S.cr concentration postexercise in morning and evening group are significant higher than Pre-exercise in the same time, the Bun., S.cr concentration post-exercise in the evening group are higher than post-exercise in morning group $(p \geq 0.05)$. But no significant $(P \geq 0.05)$ in Sodium and Potassium. While the SYS and DIS blood Pressure level post-exercise are significant lower than Pre-exercise in the morning and evening group, and found that the SYS and DIS blood Pressure post-exercise in evening group are lower In comparison with post-exercise in morning group ( $\mathrm{p} \geq 0.05$ ).

Conclusion: The physical exercise cause significantly higher in Bun and S.cr, the concentration of Bun and S.cr post-exercise in evening time are higher than postexercise in morning time, no significant was appeared in sodium and potassium levels. Conversely, significantly lower in SYS and DIS blood Pressure postexercise.While, SYS and DIS blood Pressure post-exercise in evening time are significant lower In comparison with post-exercise in morning time
\end{abstract}

Keywords: physical exercise, pre-exercise, post-exercise, renal function test, blood Pressure. 


\section{University of Thi-Qar Journal Vol.11 No.3 SEP 2016}

Web Site: https://jutq.utq.edu.iq/index.php/main Email: journal@jutq.utq.edu.iq

\section{Introduction}

Exercise is an important function of living systems, it effects many systems in our body, human body adapts to exercise by breathing and by cardiovascular systems such as cardiac output is 20-25 liters during high intensity exercise (1). Some studies proved that regular exercises have a positive effect on all body systems, and prevent formation of health problems (2). Prolonged strenuous physical exercise (PSPE) has a strong influence on human metabolism, (3). as well as many of studies investigated the short-term influence of episodic strenuous physical exercises on some biochemical analyses (4). There are changes in blood parameters in line with the intensity, duration and type of the exercise, may be observed this changes in the blood values during and after an intense exercise because of differences in exercise status of the individual, environmental conditions and nutrition, some researches suggesting positive improvements in the blood biochemistry as a result of acute exercise, while other studies suggesting that the changes by long-duration exercises rather than acute exercises (5)when hematology is analyzed, the effect of acute exercise on hematological levels is seen different, these differences depend on the severity, duration, exercise at different times of day and frequency of exercise as well as physical and physiological conditions of subjects (1). In addition the studies showed that daily changes or diurnal cycle of physiological responses in the body indicates the fact that physiological Responses at rest and during exercise throughout the day will change and body capabilities are subject to diurnal influences (4). the important issues in physical education that attracted the attention of many experts around the world is the role of physical activities on renal function (4) Previous studies have shown that single session of aerobic exercise can lead to changes in the immune system, urine creatinine.(4).

Exercises bring along wide range of positive adaptations such as muscular force, reaction time, neuromuscular coordination, balance, body composition, mitochondrial increase, aerobic-anaerobic capacities (7) .

\section{Materials and method}

The sample was selected at random(20) from males students volunteers of the second stage (College of Physical Education ) University of Basra, (10) students from the morning group and (10) students from the evening group. The heights, weights, and $5 \mathrm{cc}$. venous blood samples of subjects were taken before the exercise, 
Which lasted one and a half hour. the $5 \mathrm{cc}$. venous blood samples were taken again just after the exercise before drinks water or any fluid in sitting position and injected in gel tubes. Blood sample (for morning exercise), was taken at 09:00 and 10:00 (pre- and post- exercise). Blood sample (for evening exercise) was taken at 14:00 and 15:00 (pre- and post- exercise). Serum was obtained by Centrifugation for (blood urea nitrogen, serum creatinine, sodium and potassium) tests . Blood pressure (systolic and diastolic) was measured from the brachial artery, in the right arm in a sitting position using a standard mercury sphygmomanometer, before the exercise and directly after the exercise.

\section{Statistical analysis:}

The researcher used the statistical program (spss) in data processing and extract results, the statistical methods used (ANOVA test, arithmetic mean test, and standard deviation).

\section{Results:}

Table1: shows the Mean, standard deviation and The coefficient of variation to age, body weight, height of the subjects in morning group and evening group $(\mathrm{N}=20)$. The values were expressed as mean $\pm \mathrm{SD}$.

\begin{tabular}{|c|c|c|c|c|c|c|c|c|}
\hline \multirow{2}{*}{ NO } & \multirow{2}{*}{ variables } & \multicolumn{3}{|c|}{ Morning Group } & \multicolumn{3}{|c|}{ Evening Group } & \multirow{2}{*}{$\mathrm{P} \leq \mathbf{0 . 0 5}$} \\
\hline & & Mean & SD士 & c.v & Mean & SD \pm & $\overline{c . v}$ & \\
\hline 1 & Height (cm) & 176.7 & 7.846 & 4.44 & 178.8 & 10.358 & 5.793 & NS \\
\hline 2 & Body Weight (kg) & 66.5 & 5.911 & 8.88 & 67 & 4.824 & 7.2 & NS \\
\hline 3 & Age(year) & 21.5 & 0.849 & 3.948 & 22 & 1.052 & 4.781 & NS \\
\hline
\end{tabular}

The current studywas showed thevalues of Bun.andS.cr. of the subjects before exercise (pre-exercise) and after exercise (post-exercise). However, the study appeared that the Bun \& S.cr concentration post-exercise are significant higher than pre-exercise in the morning and evening group. inaddition, The study found that the Bun, S.cr concentration post-exercise in evening group are higher than post-exercise in morning group $(\mathrm{p} \geq 0.05)$.

(Table 2) :Comprise of Kidney function test (Bun and S.cr) in pre-exercise Samples and post-exercise of morning and evening group. The values were expressed as mean \pm SD.

\begin{tabular}{|c|c|c|c|c|c|c|c|c|c|c|}
\hline \multirow{3}{*}{ NO. } & \multirow{3}{*}{$\begin{array}{l}\text { Kidney } \\
\text { Function } \\
\text { test }\end{array}$} & \multicolumn{4}{|c|}{ Morning Group } & \multicolumn{4}{|c|}{ Evening Group } & \multirow{3}{*}{$\mathrm{p} \geq \mathbf{0 . 0 5}$} \\
\hline & & \multicolumn{2}{|c|}{ Pre-Exercise } & \multicolumn{2}{|c|}{ Post-Exercise } & \multicolumn{2}{|c|}{ Pre-Exercise } & \multicolumn{2}{|c|}{ Post-Exercise } & \\
\hline & & Mean & $\overline{S D \pm}$ & Mean & $\overline{\text { SD } \pm}$ & Mean & $\overline{S D \pm}$ & Mean & $\overline{\text { SD } \pm}$ & \\
\hline 1 & BUN & 36.3 & 3.233 & $39.2^{c}$ & 3.583 & 35.51 & 4.252 & $44.34^{\mathrm{a}, \mathrm{b}}$ & 9.569 & 2.801 \\
\hline 2 & S.cr & 0.907 & 0.135 & $1.197^{\mathrm{c}}$ & 0.176 & 1.027 & 0.107 & $1.799^{\mathrm{a}}$ & 0.25 & 0.175 \\
\hline
\end{tabular}




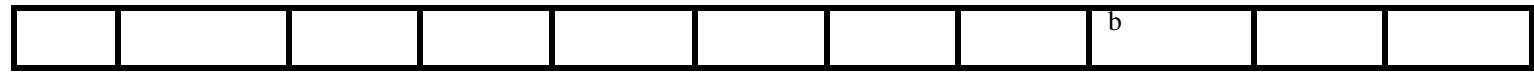

Moreover, as shown in the (table 3), the results showed, in spite of present mean differences between groups observed in the values (Sodium and Potassium ), but these changes were not significant $(\mathrm{P} \geq 0.05)$.

(Table 3) : Compare the values of Sodium and Potassium in pre-exercise Samples and post-exercise Samplesof morning and evening group.The values were expressed as mean $\pm \mathrm{SD}$.

\begin{tabular}{|c|c|c|c|c|c|c|c|c|c|c|}
\hline \multirow{3}{*}{ NO } & & \multicolumn{4}{|c|}{ Morning Group } & \multicolumn{4}{|c|}{ Evening Group } & \multirow{3}{*}{$\mathrm{p} \geq \mathbf{0 . 0 5}$} \\
\hline & & \multicolumn{2}{|c|}{ Pre-Exercise } & \multicolumn{2}{|c|}{ Post-Exercise } & \multicolumn{2}{|c|}{ Pre-Exercise } & \multicolumn{2}{|c|}{ Post-Exercise } & \\
\hline & & Mean & SD \pm & Mean & SD \pm & Mean & SD \pm & Mean & SD \pm & \\
\hline 1 & $\mathbf{N a}$ & 143.3 & 7.196 & 139.3 & 5.313 & 139.8 & 4.685 & 137.5 & $\overline{5.296}$ & NS \\
\hline 2 & $\mathbf{K}+$ & 4.49 & 0.834 & 4.51 & 0.699 & 4.40 & 0.801 & 4.43 & 0.743 & NS \\
\hline
\end{tabular}

Anyhow, the current results showed, that values of SYS and DIS blood Pressure level post-exercise are significant lower than pre-exercise in the morning and evening group, and found that the SYS and DIS blood Pressure post-exercise in evening group are lower in comparison with post-exercise in morning group $(\mathrm{p} \geq 0.05)$.

Table 4 : Compare of blood Pressure (SYS. and DIS.) in Pre-exercise Samples and Post-exercise samples of morning and evening group.The values were expressed as mean \pm SD.

\begin{tabular}{|c|c|c|c|c|c|c|c|c|c|c|}
\hline \multirow{3}{*}{ NO } & \multirow{3}{*}{$\begin{array}{l}\text { Blood } \\
\text { Pru. }\end{array}$} & \multicolumn{4}{|c|}{ Morning Group } & \multicolumn{4}{|c|}{ Evening Group } & \multirow{3}{*}{$\mathrm{p} \geq 0.05$} \\
\hline & & \multicolumn{2}{|c|}{ Pre-Exercise } & \multicolumn{2}{|c|}{ Post-Exercise } & \multicolumn{2}{|c|}{ Pre-Exercise } & \multicolumn{2}{|c|}{ Post-Exercise } & \\
\hline & & Mean & $\mathrm{SD} \pm$ & Mean & SD \pm & Mean & $\mathrm{SD} \pm$ & Mean & SD \pm & \\
\hline 1 & SYS. & 133 & 5.27 & $120.5^{b}$ & 6.433 & 136 & 16.193 & $119.7^{\mathrm{a}}$ & 33.24 & 10.88 \\
\hline 2 & DIS. & 88 & 1.699 & $83.1^{\mathrm{b}}$ & 2.842 & 93.4 & 6.832 & $82.5^{\mathrm{a}}$ & 3.541 & 4.122 \\
\hline
\end{tabular}

\section{Discussion}

The current study showed that there is a significant difference between pre-test and post-test in creatinine excretion among research subjects in the morning and evening times ( $\mathrm{p} \geq 0.05$ ). Furthermore, the study current found that the increased in excretion of creatinine among investigate subjects of evening times (post-test) is significantly more than the morning time (post-test), this result consistent with (Babaee et al 2013) and (Ebrahim, et al 2015). But inconsistent with other workers (Mantel 


\section{University of Thi-Qar Journal Vol.11 No.3 SEP 2016}

Web Site: https://jutq.utq.edu.iq/index.php/main Email: journal@jutq.utq.edu.iq

Pierre et al 2002) and (Lippi et al 2008). Though, ehecreatinine levels increment with heavy exercise. The changes that occur in the serumcreatinine during physical activity. In other word, is different depending on the type of exercise, intensity, duration and type of metabolism. Therefore, (Ebrahim, et al 2015), who reported that the main reasons for the increase in serum creatinine in athletes which appeared that are seems due to reduction in renal blood flow and glomerular filtration reduction in intense physical activity.

The research results showed that there is a significant difference between pre-test and post-test of subjects in blood urea nitrogen (Bun) in the morning and in the evening ( $\mathrm{p} \geq 0.05$ ). And we found that increased in blood urea nitrogen (Bun) among research subjects of evening times (post-test) is significantly more than the morning time (post-test) , this result consistent with the (Lin et al , 2011) and (Li et al, 2012). But inconsistent with the research results of (Nahid\&, Samaneh , 2013) and ( RafatiFardet al , 2011). The liver produces urea in the urea cycle as a waste product of the digestion of protein.(Macedo, 2011). Bun is an indication of renal health, increased of Bun probably is physiologic response to the decrease of blood flow of the kidney (as a result of dehydration) and not a sign of renal failure, increased of Bun reveals that protein catabolism becomes the dominant biochemical process in the body of the Athletes, which may have a negative impact on the body energy storage and disorder the process of glomerular filtration rate (Li et al., 2012).

It seems that time, intensity and volume of training can have an impact on renal function. The results of some studies suggest that changes in the cellular immune system and urinary system following of physical exercise session between evening group and the morning group, time (morning and evening) and time group interaction showed a significant difference. Ebrahim, et al (2015).

The Current research result showed that there is no significant difference between pre-test and post-test in serum sodium concentration among research subjects in the morning and in the evening times $(\mathrm{p} \geq 0.05)$. This result consistent with the (Bilgehan , 2013).\& (Ugwuja, et a el , 2014). and inconsistent with the (Pourvaghar and Soori , 2007 ).and (Noakes , 2002) it seems intensity and exercise duration effect on sodium concentration (Ugwuja, et al, 2014).

sodium concentration were not effected by the exercise, the non-significant changes in sodium concentration may be due to the short duration of exercise in our study. (Bilgehan ,2013). 


\section{University of Thi-Qar Journal Vol.11 No.3 SEP 2016}

Web Site: https://jutq.utq.edu.iq/index.php/main Email: journal@jutq.utq.edu.iq

also The Current research result showed that there is no significant difference between pre-test and post-test in serum Potassium concentration among research subjects in the morning and in the evening times $(\mathrm{p} \geq 0.05)$. the present research consistent with (Pourvaghar and Soori, 2007 ).\& (Ugwuja, et al , 2014) and inconsistent with (Barlowset al. 1994 \& Tanabe et al, 1999).

The levels of many minerals show variation depending on the kind of exercise, fitness status of the participants (Bilgehan ,2013). The main reason for nonsignificant in concentration of serum potassium was type, intensity and duration of exercise (Pourvaghar and Soori, 2007 ).

The current study showed that there is a significant difference between pre-test and post-test in blood Pressure among research subjects in the morning and evening times $(p \geq 0.05)$.and we found that increased in blood Pressure among research subjects of evening times (post-test) is significantly more than the morning time (post-test), this result consistent with the (Jovenes,2015 \& Benjamin , 2011) Moderate intensity physical exercise has been shown to reduce systolic BP for 11 to 12 hours and diastolic BP for 4 to 8 hours post-exercise, this may be due to the increased peripheral vasodilation, hypotension Post exercise as a result of reduced vascular resistance by the autonomic nervous system and regulation of multiple vasodilatory mechanisms ( Benjamin, 2011). The research of Benjamin suggests that the timing of Physical exercise also may influence on the BP system. Park et al.concluded that exercise in the evening exhibited a greater reduction in systolic pressure (Park et al , 2005), another potential mechanism for the BP response to exercise timing may be the influence of the circadian rhythms throughout the day (Somers et al,1991).

\section{References :}

1. Ibrahim , E. (2013). The comparison of blood parameters between morning and evening exercise. 3(1):559-563.

2. Sönmez G.T. (2002). Physiology of Exercises and Sports . 37- 75.

3. Giuseppe, L. ; Giorgio, B. ; Massimo, F. ; Federico, S. and Giancesare, G.( 004). Comparison of serum creatinine, uric acid, albumin and glucose in male professional endurance athletes compared with healthy controls .42(6):644-647.

4. Neumayr, G. ;Pfister, R. ;Hoertnagl, H. ;Mitterbauer, G. ; Getz-ner, W. and lmer, H .(2003) the effect of marathon cycling on renal function. 24:131-7. 


\section{University of Thi-Qar Journal Vol.11 No.3 SEP 2016}

Web Site: https://jutq.utq.edu.iq/index.php/main Email: journal@jutq.utq.edu.iq

5. Ragip, Pala (2013). Examining certain blood parameters of sporters of national boxing team before and after the match . 3(1):327-331.

6. Ebrahim, M. J. ; Mohamed, H.S. and Ebrahim, K. (2015). Comparing the effects of one-session aerobic exercise in the morning evening on the immune system and urinary compounds among body builders.4(3): 1649-1663.

7. Cooper, D.M. ;Nemet, D. Galassetti, P. (2004). Current Opinion in Pediatrics 6(3): 286-292.

8. Babaee, R. (2013). Effect of movement patterns and intensity of physical activity on the amount and type of exercise protein in active young men, quarterly health family $1(1)$.

9. Montelpare, W. P. ;Klentrou and Thoden (2002). Continuous versus intermittent exercise effects on urinary excretion of albumin and total protein. 5(3): 219-228.

10. Lippi, G. et al. (2008). Acute variation of estimated glomerular filtration rate

11. following a half-marathon run. 29(12): 948.

12. Lin Q; Lin, R. Ji Q, Zhang, J. Wang, W. Yang, L. et al., (2011). Effect of exercise training on renal function and renal aquaporin-2 expression in rats with chronic heart failure. 38:179-185.

13. Li Y; Zhu Y; Zhang, J. ; Zhang, X. Zeng Y. (2012). Biochemical changes and endocrine responses in precompetition training in elite swimmers. . 29:71-75.

14. Nahid, B. ;Samaneh, F. (2013). The Effect of six months of aerobic training on renal function markers in untrained middle-aged women. 3 (2), 218-224.

15. Rafati, F. M;Taghian, F. ;Pakfetrat, M. ;Daryanoosh, F. and mohammadi, H. (2011). The Effect of aerobic training on the amount of GFR and excreted of Creatinine in Patients with Chronic kidney. 9(4): 264-270.

16. Macedo E, 2011. Blood urea nitrogen beyond estimation of renal function. Critical Care medicine, 39(2): 405-406.

17. Bilgehan, B. (2013). Serum Macro-Micro Element Responses to Acute Maximal Physical Exercise. 23 (7): 945-949.

18. Ugwuja, S. E. ;Obeagu , E. I. ;Ochei, K. C. ;Ogbu, R.O. andAgoha, S. C. (2014). Effect Of Physical Exercises On Serum Electrolyte. 13(9) 2279-0861.

19. Pourvaghar,M. J. andSoori, R.(2007). A Survey of Sodium and Potassium Alterations during Rest Time after Aerobic Activities in Athletes . 1(4): 687-690.

20. Noakes,T. (2002). Hyponatraemia in distance runners;fluid and Sodium balance during exercise. Current sports medicine representatives 1:197-207.

21. Ugwuja, S. E. ;Obeagu, E. I. ;Ochei, K. C. ;Ogbu, R. O.andAgoha, S. C. (2014). Effect of Physical Exercises On Serum Electrolyte 13 (9) : 118-121. 


\section{University of Thi-Qar Journal Vol.11 No.3 SEP 2016}

Web Site: https://jutq.utq.edu.iq/index.php/main Email: journal@jutq.utq.edu.iq

22. Barlows,C.W. ;Qayyum,D. et al. (1994). Circulation, 89: 1144-1152.

23. Tanabe,Y. ;Ito,M. ;Hosaka, Y. ; Ito, E. and Suzuki,K. et al. (1999). Chest, 116: 8896.

24. Jovenes, Y. ;Normotensos. ( 2015) Hipotensaopos-exercicio de homensjovennsenormotensosemsessoes de corridaempista 21( 3 ).

25. Benjamin, w, C. (2011). Effects of aerobic exercise on nocturnal blood pressure dipping in prehypertensive individuals.

26. Park, S. ;Jastremski,C.A. and Wallace, J.P. (2005).Time of day for exercise on blood pressure reduction in dipping and nondipping hypertension. 19(8):597-605.

27. Somers, V.K ; Conway, J.; Johnston, J.and Sleight, P.( 1991). Effects of endurance training on baroreflex sensitivity and blood pressure in borderline hypertension. 337(8754):1363-8.

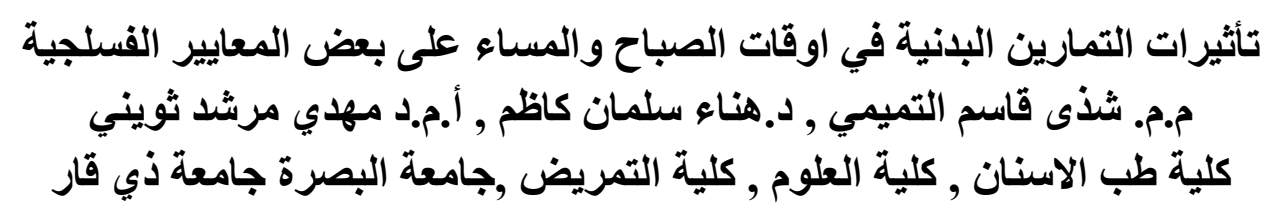

الخلاصة : مان

هدفت الدراسة الحالية الى مقارنة تأثثر التمارين الرياضية في وقت الصباح والمساء على بعض المعايير

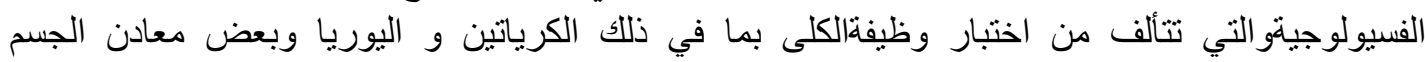
(الصوديوم و البوتاسيوم) و ضغط الدم ، شملت الدر اسة (20) طالب من طلاب المرحلة الثانية في كلية التربية

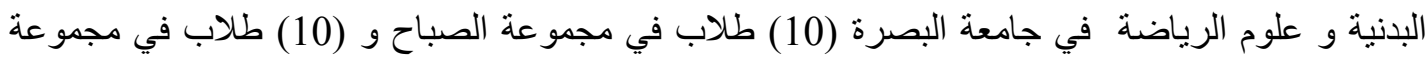

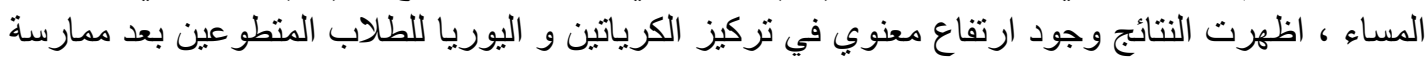

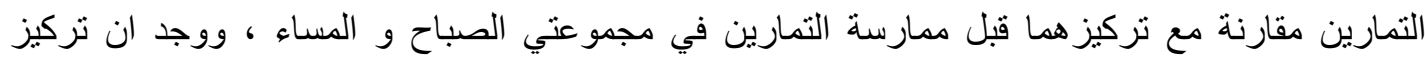

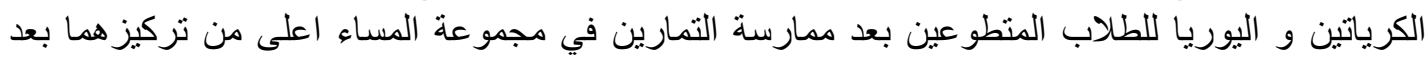

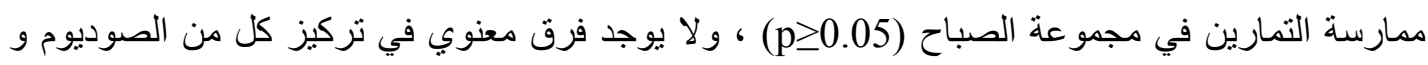

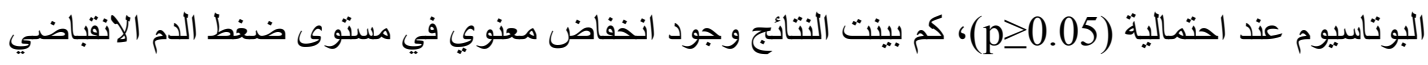

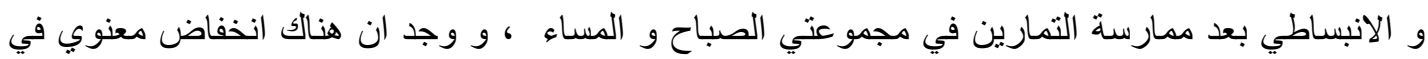

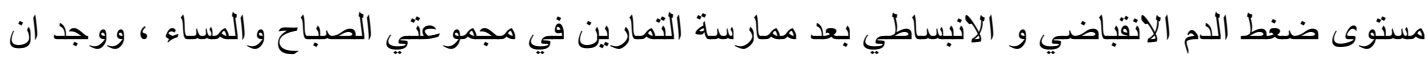

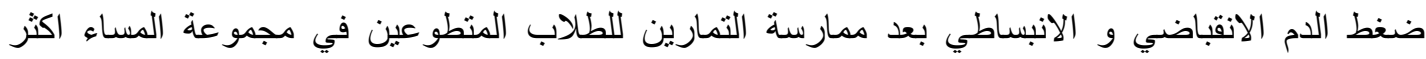
انخفاضـا عنه في مستوى ضغط الدم بعد ممارسة التمارين في مجمو عة الصباح (p>0.05). 